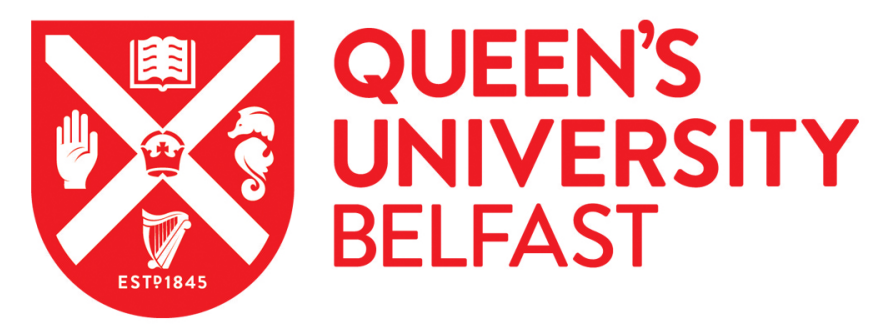

\title{
Temperature rise and parasitic infection interact to increase the impact of an invasive species
}

\author{
Laverty, C., Brenner, D., Mcllwaine, C., Lennon, J. J., Dick, J. T. A., Lucy, F. E., \& Christian, K. A. (2017). \\ Temperature rise and parasitic infection interact to increase the impact of an invasive species. International \\ Journal for Parasitology, 47(5), 291-296. https://doi.org/10.1016/j.ijpara.2016.12.004
}

Published in:

International Journal for Parasitology

Document Version:

Peer reviewed version

Queen's University Belfast - Research Portal:

Link to publication record in Queen's University Belfast Research Portal

Publisher rights

(c) 2017 Elsevier Ltd.

This manuscript version is made available under the CC-BY-NC-ND 4.0 license http://creativecommons.org/licenses/by-nc-nd/4.0/ which permits distribution and reproduction for non-commercial purposes, provided the author and source are cited.

\section{General rights}

Copyright for the publications made accessible via the Queen's University Belfast Research Portal is retained by the author(s) and / or other copyright owners and it is a condition of accessing these publications that users recognise and abide by the legal requirements associated with these rights.

Take down policy

The Research Portal is Queen's institutional repository that provides access to Queen's research output. Every effort has been made to ensure that content in the Research Portal does not infringe any person's rights, or applicable UK laws. If you discover content in the Research Portal that you believe breaches copyright or violates any law, please contact openaccess@qub.ac.uk. 
1 Temperature rise and parasitic infection interact to increase the

2 impact of an invasive species

3 Ciaran Laverty ${ }^{\mathrm{a}}$, David Brenner ${ }^{\mathrm{b}}$, Christopher McIlwaine ${ }^{\mathrm{a}}$, Jack J. Lennon ${ }^{\mathrm{a}}$, Jaimie T. A.

$4 \quad$ Dick $^{\mathrm{a},{ }^{*}}$, Frances E. Lucy ${ }^{\mathrm{c}}$, Keith A. Christian ${ }^{\mathrm{d}}$

5 anstitute for Global Food Security, School of Biological Sciences, Queen’s University

6 Belfast, MBC, 97 Lisburn Road, Belfast, Northern Ireland, BT9 7BL, UK

$7 \quad$ bepartment of Ecology and Parasitology, Institute of Zoology, School of Chemical and

8 Biological Sciences, Karlsruhe Institute of Technology, Germany

$9 \quad{ }^{\mathrm{c} C e n t r e ~ f o r ~ E n v i r o n m e n t a l ~ R e s e a r c h ~ I n n o v a t i o n ~ a n d ~ S u s t a i n a b i l i t y, ~ D e p a r t m e n t ~ o f ~}$

10 Environmental Science, Institute of Technology, Sligo, Ireland

$11{ }^{\mathrm{d}}$ Research Institute for Environment and Livelihoods, Charles Darwin University, Darwin, $12 \quad$ NT 0909, Australia

$14 *$ Corresponding author.

E-mail address: j.dick@qub.ac.uk (J Dick)

16

17 


\section{Abstract}

Invasive species often detrimentally impact native biota, eg through predation, but predicting such impacts is difficult due to multiple and perhaps interacting abiotic and biotic context dependencies. Higher mean and peak temperatures, together with parasites, might influence the impact of predatory invasive host species additively, synergistically or antagonistically. Here, we apply the comparative functional response methodology (relationship between resource consumption rate and resource supply) in one experiment and conduct a second scaled-up mesocosm experiment to assess any differential predatory impacts of the freshwater invasive amphipod Gammarus pulex, when uninfected and infected with the acanthocephalan Echinorhynchus truttae, at three temperatures representative of current and future climate. Individual G. pulex showed Type II predatory functional responses. In both experiments, infection was associated with higher maximum feeding rates, which also increased with increasing temperatures. Additionally, infection interacted with higher temperatures to synergistically elevate functional responses and feeding rates. Parasitic infection also generally increased $\mathrm{Q}_{10}$ values. We thus suggest that the differential metabolic responses of the host and parasite to increasing temperatures drives the synergy between infection and temperature, elevating feeding rates and thus enhancing the ecological impact of the invader. impact 
41

42

43

44

\section{Introduction}

Invasive species are driving changes in community structure and function throughout the world at an increasing rate (Simberloff et al., 2013; Dick et al., 2014). This includes reductions in native species richness, diversity and abundance (Dick et al., 2017), and even species extinctions (Clavero and Garcia-Berthou, 2005), with consequent disruption of ecosystem functions and services (Strayer, 2012). Further, climate change due to human activity is a global phenomenon and is predicted to influence invasive species spread and ecological impacts (Walther et al., 2009; Sorte et al., 2013; Morley and Lewis, 2014). For example, increasing temperatures may favour invasive species by providing their thermal optima, such as with the bloody-red shrimp, Hemimysis anomala, the predatory impacts of which increase with temperature to the point of excluding native species (Dick et al., 2013; Iacarella et al., 2015). In aquatic systems, climate change will manifest in changes in temperature regimes that may interact with other factors to influence invasion outcomes and impact (Ansa-Asare et al., 2000; Portner and Knust, 2007). Exploring such interactions among invasions and abiotic and biotic factors, or "context dependencies” in the invasion literature (see Dick et al., 2017), may help us understand and predict the impacts of ongoing and new species invasions in a changing world (Dick et al., 2014). As an example, the environmental context of decreasing dissolved oxygen in rivers will likely increase the ecological impacts of invasive crustaceans (Laverty et al., 2015).

Furthermore, parasitic infection is a pervasive feature of biological communities that is increasingly recognised as playing a pivotal role in determining the outcomes of species interactions and shaping community structure (Wood et al., 2007; Hatcher and Dunn, 2011; Hatcher et al., 2014). Whilst both temperature and parasitic infection separately can affect the impact of invasive species (Dick et al., 2010; Sorte et al., 2013; Iacarella et al., 2015), the 
interaction of temperature with infection in determining invasive species impacts has not been explored. A powerful method in predicting the ecological impacts of invading consumers (e.g. predators) on native resources (e.g. prey) is the use of comparative functional responses (Dick et al., 2014, 2017). This method uses the relationship between resource consumption rate and resource density to derive differences in the estimated maximum feeding rates of invader and native species; these patterns corroborate with known ecological impacts of invaders in the field (Dick et al., 2013, 2014, 2017; Alexander et al., 2014; Laverty et al., 2015). In essence, functional responses describe the effects on prey populations of a predator, and higher functional responses translate into higher ecological impact (e.g. Dick et al., 2013, 2017). Here, we use comparative functional responses to investigate the relationship between native prey consumption by an invasive predator, as influenced by the interaction between parasitic infection and increasing temperature.

Native to Europe but invasive in Ireland and other islands, the freshwater amphipod Gammarus pulex has replaced the native Irish amphipod Gammarus duebeni celticus and negatively impacted native macroinvertebrate communities (Kelly et al., 2003, 2006; Dick, 2008; Franceschi et al., 2008; Grabner et al., 2014). Gammarus pulex is an intermediate host to the fish acanthocephalan parasite Echinorhynchus truttae which, when developmentally ready for trophic transmission, alters host behaviour (eg drift, micro-habitat use) to facilitate consumption by its final host, brown trout (MacNeil et al., 2003). Gammarus pulex has also been shown to consume more prey when infected with E. truttae, which can reach $70 \%$ prevalence in host populations (eg in Ireland; Dick et al., 2010). Here, we therefore tested whether increased water temperatures will lead to simple additive or complex synergistic/antagonistic changes in the impact on prey populations of this invasive predator in the context of infection with the acanthocephalan. This is achieved by deriving functional responses (the relationship between prey density and prey consumption rate) under 
infection/temperature combinations and exploring the interaction of these contexts on the estimated maximum feeding rate, and hence ecological impact, of this invader. Then, this individual-based approach is scaled up to a mesocosm experiment that more realistically mimics field conditions of multiple conspecific predators. Finally, we use $\mathrm{Q}_{10}$ values (eg see Bennett, 1990) to further explore any change in feeding rates and hence ecological impact of the invader associated with parasitic infection as temperature increases.

\section{Materials and methods}

\subsection{Animal collection and husbandry}

Gammarus pulex were collected from an unpolluted 25 m stretch of the Minnowburn River, Northern Ireland (N54.548; W5.952 ) in May 2014 (Experiment (Expt.) 1) and May 2016 (Expt. 2) and transported in source water to the Queen’s University Belfast (Northern Ireland) laboratories. In each year, over 4 weeks, we collected four such samples of G. pulex, of several hundred animals each. Those infected with E. truttae were identified by visual inspection of the haemcoel, with parasite status checked by dissection following the experiments. Infected and uninfected G. pulex (size and age matched adult males, body length $1.5-1.8 \mathrm{~cm}$ ) from each collection were kept in multiple batches of approximately 20 animals in $2 \mathrm{~L}$ of continuously aerated source water and fed decaying leaves ad libitum at $11^{\circ} \mathrm{C}$ with a $12: 12 \mathrm{~h}$ light:dark cycle, for 1 week before use in experiments. We chose to use naturally infected animals because infection in the wild is essentially random, and host behavioural manipulations due to the parasite only manifest when the parasite is mature (Franceschi et al., 2008). That is, the parasite drives host behavioural modifications, rather than differences between potential hosts driving parasite acquisition. Experimental prey were chironomid larvae (0.4-0.8 cm body length) obtained online from FishAround Ltd. (UK; 
http://fisharoundltd.com/); we used live prey in Expt. 1, but switched to thawed frozen prey for Expt. 2 due to the logistics of the large numbers of prey required. Individual predators were starved for $24 \mathrm{~h}$ to standardise hunger.

\subsection{Experimental methods}

We used filtered Minnowburn River water (Grade 1, $11 \mu \mathrm{m}$ Qualitative filter paper to remove suspended material) in replicates undertaken with a 12:12 h light:dark cycle over 24 h, in: (Expt.1) experimental arenas $7 \mathrm{~cm}$ in diameter with $100 \mathrm{ml}$ of water; and (Expt. 2) three separate cylindrical experimental arenas $10 \mathrm{~cm}$ in diameter with $500 \mathrm{ml}$ of water. Water temperatures were $11^{\circ} \mathrm{C}, 16^{\circ} \mathrm{C}$ and $20^{\circ} \mathrm{C}$, representing reasonable current autumn/winter, spring/summer and future summer temperatures (in line with the UK Climate Impacts Program 2002 (UKCIP02)

http://danida.vnu.edu.vn/cpis/files/Papers_on_CC/CC/Climate\%20Change\%20Scenarios\%20 for\%20the\%20United\%20Kingdom.pdf; Hulme et al., 2002) and reasonable temperature swings throughout the daily cycle of UK freshwaters, and increased future mean temperatures (Hammond and Pryce, 2007). The maximum $20^{\circ} \mathrm{C}$ water temperature in this experiment is also currently experienced on hot summer days, but is below temperatures where G. pulex shows significant mortality (e.g. $40 \%$ mortality at $25^{\circ} \mathrm{C}$; Grabner et al., 2014). All replicates were carried out in Clifton NE1B-14 water baths at $11^{\circ} \mathrm{C}, 16^{\circ} \mathrm{C}$ or $20^{\circ} \mathrm{C}\left( \pm 0.1^{\circ} \mathrm{C}\right.$, unstirred). In both experiments, predators and prey were acclimated to each temperature over $2 \mathrm{~h}$ prior to experiments; this was achieved for the two higher temperatures by gradually increasing the water bath temperature every $30 \mathrm{~min}$ by either $1.25^{\circ} \mathrm{C}$ or $2.25^{\circ} \mathrm{C}$ (i.e. to $16^{\circ} \mathrm{C}$ or $20^{\circ} \mathrm{C}$ ). In Expt. 1, we then introduced single predators (i.e. G.pulex either uninfected or infected) to each experimental arena with prey densities of $2,4,6,8,10,20$ and 40 ( $n=3$ per experimental 
group); in Expt. 2, each of the three arenas contained 10 G. pulex and 300 prey (i.e. in excess) with the following proportions of infected G. pulex; zero infected (0\%) five individuals infected (50\%), and seven individuals infected (70\%) with $n=4$ per experimental group. Oxygen was monitored using a YSI model 550A (UK) dissolved oxygen meter, with oxygen levels kept between 9.50 and $10.50 \mathrm{mg} / \mathrm{l}$ by bubbling air for $1 \mathrm{~min}$, when required, through both predator and control replicates. Controls were prey in the absence of predators in the prey density/temperature/parasite groups as above ( $n=3$ per group). When experiments were finished, individual G. pulex were killed using hot water and confirmed for the presence/absence of a single E. truttae parasite. All individuals were found to have been visually ascribed correctly as uninfected or harbouring E. truttae.

\subsection{Statistical methods}

All statistical analyses were conducted in R v3.0.2. Functional responses were considered to be Type II when there was a significant negative first order linear coefficient from logistic regressions (proportion of prey killed versus prey density) and functional response curves were fitted using Rogers’ random predator equation without prey replacement (Trexler et al., 1988; Juliano, 2001):

$$
N_{e}=N_{0}\left(1-\exp \left(a\left(N_{e} h-\mathrm{T}\right)\right)\right)
$$

where $N_{e}$ is the number of prey eaten, $N_{0}$ is the initial density of prey, $a$ is the attack constant, $h$ is the handling time and $\mathrm{T}$ is the total experimental period, in this case $24 \mathrm{~h}$. Model fitting used the Lambert W function (Bolker, 2008) in R due to the implicit nature of the random predator equation. As data were not normally distributed (Shapiro-Wilks $W$-test, $P<0.05$ ) and heteroscedastic (Bartlett's test, $P<0.05$ ), we used ANOVA (with Tukey’s post-hoc tests) on 
$\log _{10}$ transformed bootstrapped $(n=30)$ functional response data to test for differences in the estimated maximum feeding rate ' $1 / \mathrm{hT}$ ' $(\mathrm{T}=$ experimental time, $\mathrm{h}=$ handling time; where handling time is the efficiency of capturing and consuming prey) between uninfected and infected G. pulex at the three experimental temperatures. We also calculated $\mathrm{Q}_{10}$ values to quantify the effect of increased temperature and to further examine the effect of infection on feeding rates as temperatures increased:

$$
Q_{10}=\left(\frac{R_{2}}{R_{1}}\right)^{\left(\frac{10}{T 2-T 1}\right)}
$$

where $\mathrm{Q}_{10}$ is a coefficient without units, $\mathrm{R}_{1}$ is the maximum feeding rate at temperature $\mathrm{T}_{1}$ and $\mathrm{R}_{2}$ is the maximum feeding rate at temperature $\mathrm{T}_{2}$. Values used in the $\mathrm{Q}_{10}$ analysis can be found in Table 1. The $\mathrm{Q}_{10}$ coefficient measures the increase in the rate of a biological process as temperature increases by $10^{\circ} \mathrm{C}$ (Bennett, 1990). Q 10 values of $2 \sim 4$ are associated with rapid increases in activity rates as temperatures increase, while values of 1 1.5 are associated with reaching a thermal plateau (Huey, 1982; Bennett, 1990).

As data from Expt. 2 were not normally distributed (Shapiro-Wilks $W$-test, $P<0.05$ ) and heteroscedastic (Bartlett’s test, $P<0.05$ ), we used ANOVA (with Tukey’s post-hoc tests) on $\log _{10}$ transformed feeding data to test for differences in the mean numbers of prey eaten with respect to infection and temperature treatments. $Q_{10}$ values were then calculated for each infection treatment as temperatures increased in a similar manner to Expt. 1. Values used in this $\mathrm{Q}_{10}$ analysis can be found in Table 2 .

\section{Results}


Control prey survival was $>98 \%$ under all conditions after $24 \mathrm{~h}$ in Expt. 1, therefore

184

185

186

187

deaths in experimental groups were attributed to predation by G. pulex. All functional response curves were Type II (Fig. 1, Table 3). Estimated maximum feeding rates were significantly higher for infected animals ( $\mathrm{F}_{1,174}=646.78, P<0.001$, Figs. 1,2$)$ and increased significantly with temperature $\left(F_{2,174}=667.43, P<0.001\right.$, Figs. 1,2$)$; additionally, infection elevated maximum feeding rates to a greater degree at the higher temperatures as shown by the significant 'infection $x$ temperature' interaction effect $\left(F_{2,174}=3.05, P<0.05\right.$, Figs. 1, 2). Infected amphipod $\mathrm{Q}_{10}$ values indicate that, from $11-16^{\circ} \mathrm{C}\left(\mathrm{Q}_{10}=2.57\right.$, Table 1$), 16-20^{\circ} \mathrm{C}$ (2.23, Table 1$)$ and overall from $11-20^{\circ} \mathrm{C}(2.41$, Table 1$)$, the estimated maximum feeding rates rapidly increased with the increases in temperature. Uninfected amphipods had a rapid increase in maximum feeding rate from $11-16^{\circ} \mathrm{C}(3.11$, Table 1$)$ and then it slowed considerably from $16-20^{\circ} \mathrm{C}(1.55$, Table 1$)$, and overall it is a lesser increase (2.37, Table 1$)$ than for infected amphipods (2.41, Table 1).

In Expt. 2, maximum feeding rates were significantly higher for infected treatment groups $\left(F_{2,27}=84.1, P<0.001\right.$; Fig. 3$)$ and increased significantly with temperature $\left(F_{2}\right.$, ${ }_{27}=77.2, P<0.001$; Fig. 3); additionally, as with Expt. 1, infection elevated maximum feeding rates to a greater degree at the higher temperatures as shown by the significant 'infection $\mathrm{x}$ temperature' interaction effect $\left(F_{2,27}=2.8, P<0.05\right.$ : Fig. 3$)$. For the $50 \%$ infection treatment, $\mathrm{Q}_{10}$ values indicate that from $11-16^{\circ} \mathrm{C}\left(\mathrm{Q}_{10}=2.23\right.$, Table 2$), 16-20^{\circ} \mathrm{C}(1.38$, Table 2$)$ and overall from $11-20^{\circ} \mathrm{C}(1.81$, Table 2$)$, maximum feeding rates rapidly increased with the increases in temperature. For the 70\% infection treatment, $\mathrm{Q}_{10}$ values indicated that from 11$16^{\circ} \mathrm{C}$ (1.55, Table 2), $16-20^{\circ} \mathrm{C}$ (1.53, Table 2) and overall from $11-20^{\circ} \mathrm{C}$ (1.54, Table 2$)$ maximum feeding rates also rapidly increased with the increases in temperature. Uninfected amphipods had an increase in maximum feeding rate from $11-16^{\circ} \mathrm{C}(1.56$, Table 2$)$ and with 
it plateauing from $16-20^{\circ} \mathrm{C}$ (1.19 Table 2$)$, and overall it was a lower increase (1.39, Table 2) than infected groups of amphipods (50\%: 1.81; 70\%: 1.54, Table 2).

\section{Discussion}

Predicting the impacts of invasive species requires the incorporation of both abiotic and biotic context dependencies (Ricciardi et al., 2013; Dick et al., 2014, 2017; Paterson et al., 2015). For example, water salinity, temperature and dissolved oxygen can all modify the strength of interactions between invasive and native species (Kestrup and Ricciardi, 2009; Iacarella et al., 2015; Laverty et al., 2015). Parasites are recognised as having community influences through both direct and indirect host interactions and these can drive biological invasions in terms of success and ecological impacts (Dick et al., 2010; Hatcher and Dunn, 2011; Dunn et al., 2012). Increased temperatures can also increase the consumption of prey by predators (Maier et al., 2011). Here, we show that the biotic context dependency of infection with E. truttae and the abiotic context dependency of increased temperature manifest in higher functional responses of the invader G. pulex on chironomid prey. Importantly, however, a significant synergistic interaction occurs between the two contexts and the functional response is elevated disproportionately by infection at higher temperatures. This pattern also emerges in larger scale mesocoms that more likely reflect field conditions, indicating that functional responses of individual predators are good predictors of community dynamics with multiple conspecific predators (but see Medoc et al., 2013). This pattern was further confirmed with higher $\mathrm{Q}_{10}$ values for infected $G$. pulex individuals and conspecific groups in both Expt. 1 and Expt. 2, with Q ${ }_{10}$ values higher for infected than uninfected $G$. pulex in $78 \%$ of comparisons in Tables 1 and 2. Thus, overall, this indicates that infected $G$. pulex are increasing their maximum feeding rates synergistically with temperature to a 
231

232

233

234

235

236

237

238

239

240

241

242

greater degree than uninfected G. pulex. Thus, under climate change, parasitic infection is likely to exacerbate the known ecological impacts of G. pulex invasions, which result in native gammarid species displacements and reductions in broader macroinvertebrate species richness, diversity, abundance and range (Kelly et al., 2003, 2006). These impacts may also manifest in the native range of G. pulex throughout Europe, and thus monitoring plus experimental testing are required to elucidate this point.

Maximum feeding rates, derived from functional responses, measure the predicted maximum prey consumption rate of a predator, which is a reliable indicator of impact on prey populations (Dick et al., 2013, 2014, 2017; Alexander et al., 2014; Laverty et al., 2015). Infected G. pulex consumed prey at a higher rate than those uninfected, indicating the increased ecological impact that infected invaders inflict on native communities. Such increased feeding rates driven by E. truttae in the present study likely reflect the increased metabolic demands of the host due to the reliance of the parasite on host resources (Dick et al., 2010, 2017). Higher temperatures also increased the maximum feeding rate of G. pulex, and this has ramifications for the future when water temperatures increase under climate change (Ozaki et al., 2003). Whilst we recognise that adaptation may occur, and short-term experiments may have limitations in this regard, increased temperatures clearly increase the metabolism of ectotherms. The interaction between parasitic infection and increasing temperature indicates that, as climate change occurs, parasites may have increasing influence over the impacts that invasive species propagate through native communities (Ozaki et al., 2003; Dick et al., 2010). We speculate that parasites may be increasing their metabolic rate at a higher rate than the host at higher temperatures, increasing the metabolic requirements of $G$. pulex to a greater degree than at lower temperatures, thereby increasing prey consumption rates. Also, production of heat shock proteins due to interacting factors such as parasitic infection and temperature (see Frank et al., 2013; Grabner et al., 2014) may contribute to 
256

257

258

259

260

261

262

263

264

265

266

267

268

269

270

271

272

274

275

276

277

278

279

280

higher metabolic demands and hence feeding rates of hosts. Indeed, since parasites also produce heat shock proteins (e.g. see Perez-Morales and Espinoza, 2015), any differential production by hosts and parasites may go some way towards explaining our parasite/temperature interaction. Whatever the mechanism, our results indicate that retaining natural enemies under climate change may increase rather than decrease the ecological impact of invasive species. This is counter to the 'enemy release' hypothesis (see Torchin et al., 2003; Dick et al., 2010), which posits that release from parasites may be causal in the invasion process, including increasing the ecological impact of invaders. However, our present study shows the opposite, with parasites likely increasing ecological impact, illustrating the utility of functional response analyses and mesocosms in testing popular hypotheses in invasion ecology. Finally, parasites can both increase and decrease host feeding rates (Wood et al., 2007; Larsen and Mouritsen, 2009; Dick et al., 2010; O'Shaughnessy et al., 2014; Toscano et al., 2014) and thus we require more individual studies and metaanalyses to determine why different parasites have different effects in this regard.

The use of $\mathrm{Q}_{10}$ analysis provided further evidence that the metabolic rates of amphipods increase as temperatures increase, as is commonly seen in other ectotherms (Litzgus and Hopkins, 2003; Deban and Lappin, 2011). Furthermore, in our experiments, infected individuals and groups clearly increased their metabolic rates to a greater degree than uninfected individuals, as has been noted in a number of previous studies (Booth et al., 1993; Giorgi et al., 2001; Nilsson, 2003; Dick et al., 2010). When the invader G. pulex is infected with E. truttae, such individuals are differentially affected by temperature compared with uninfected individuals and increased prey consumption is a symptom of the metabolic demand being placed upon the host by the parasite as temperatures increase. Given that $\mathrm{Q}_{10}$ values of 2 4 are associated with rapid increases in activity rates as temperatures increase, while values of 1 1.5 are associated with reaching a thermal plateau (Huey, 1982; Bennett, 
1990), it is clear that parasitic infection is driving rapid increases in host feeding rates at our study temperatures with little sign of plateau. However, plateau is more evident with uninfected compared with infected animals (Tables 1, 2). This suggests that further rises in temperature, especially under host adaptation to increased temperature, may further elevate predation rates and impacts of this and other invasive species when hosting parasites.

Overall, infected G. pulex had a greater impact than did uninfected individuals and at higher temperatures such impacts increased disproportionally. This is the first known study to examine the synergy between temperature increase and parasitic infection concerning the ecological impact of an invasive predator on recipient prey populations. Our study shows biotic and abiotic conditions interact to synergistically influence predatory impacts of invasive species and these influences should be taken into consideration when legislating against and managing invasive species (Dick et al., 2013; Sorte et al., 2013). For example, many invasive species are placed on "black lists" as they are perceived to be unwanted potential invaders (eg European Union legislation; see Caffrey et al., 2014). However, their parasites go largely ignored, and the present study indicates that parasites may enhance the ecological impacts of their hosts and this should be incorporated into any black listing in future. Further, the comparative functional response methodology, and scaled-up mesocosms, are clearly valuable tools in facilitating predictions of ecological impacts of invaders under context dependencies such as parasitic infection and temperature (see also Dick et al., 2013, 2017; Alexander et al., 2014). 
304 funding the Ph.D awarded to CL, with further support from the ITSligo President's Award 305 (Ireland). 


\section{References}

Alexander, M.E., Dick, J.T.A., Weyl, O.L.F., Robinson, T.B., David, M., Robinson, B., Richardson, D.M. 2014. Existing and emerging high impact invasive species are characterized by higher functional responses than natives Existing and emerging high impact invasive species are characterized by higher functional responses than natives. Biol. Lett. 10, 2-6.

Ansa-Asare, O.D., Marr, I.L., Cresser, M.S. 2000. Evaluation of modelled and measured patterns of dissolved oxygen in a freshwater lake as an indicator of the presence of biodegradable organic pollution. Water Res 34, 1079-1088.

Barrios-O’Neill, D., Dick, J.T.A., Emmerson, M.C., Ricciardi, A., MacIsaac, H.J., Alexander, M.E., Bovy, H.C. 2014. Fortune favours the bold: a higher predator reduces the impact of a native but not an invasive intermediate predator. J. Anim. Ecol. 83, 693701.

Bennett, A.F. 1990. Thermal dependence of locomotor capacity. Am. J. Physiol. 259, 253258.

Bolker, B.M. 2008. Ecological models and data in R. Princeton University Press, USA.

Booth, D.T., Clayton, D.H., Block, B.A. 1993. Experimental demonstration of the energetic cost of parasitism in free-ranging hosts. Proc. R. Soc. Lond. B Biol. Sci. 253, 125129.

Caffrey, J.M., Baars, J-R., Barbour, J.H., Boets, P., Boon, P., Davenport, K., Dick, J.T.A. et al. 2014. Tackling invasive alien species in Europe: The Top 20 Issues. Manag. Biol. Inv. 5, 1-20.

Clavero, M., Garcia-Berthou, E. 2005. Invasive species are a leading cause of animal extinctions. Trends Ecol. Evol. 20, 110.

Deban, S.M., Lappin, A.K. 2011. Thermal effects on the dynamics and motor control of ballistic prey capture in toads: maintaining high performance at low temperature. J. Exp. Biol. 214, 1333-1346.

Dick, J.T.A. 2008. Role of behaviour in biological invasions and species distributions; lessons from interactions between the invasive Gammarus pulex and the native $G$. duebeni (Crustacea: Amphipoda). Contrib. Zool. 77, 91-98.

Dick, J.T.A., Gallagher, K., Avlijas, S., Clarke, H.C., Lewis, S.E., Leung, S., Minchin, D., Caffrey, J., Alexander, M.E., Maguire, C., Harrod, C., Reid, N., Haddaway, N.R., Farnsworth, K.D., Penk, M., Ricciardi, A. 2013. Ecological impacts of an invasive predator explained and predicted by comparative functional responses. Biol. Invasions. 15, 837-846.

Dick, J.T.A., Alexander, M.E., Jeschke, J.M., Ricciardi, A., MacIsaac, H.J., Robinson, T.B., Kumschick, S., Weyl, O.L.F., Dunn, A.M., Hatcher, M.J., Paterson, R.A., Farnsworth, K.D., Richardson, D.M. 2014. Advancing impact prediction and hypothesis testing in invasion ecology using a comparative functional response approach. Biol. Invasions. 16, 735-753. 
Dick, J.T.A., Armstrong, M., Clarke, H.C., Farnsworth, K.D., Hatcher, M.J., Ennis, M., Kelly, A., Dunn, A.M. 2010. Parasitism may enhance rather than reduce the predatory impact of an invader. Biol. Lett. 6, 636-638.

Dick, J.T.A., Laverty, C., Lennon, J.J., Barrios-O’Neill, D., Mensink, P.J., Britton, J.R., Medoc, V., Boets, P., Alexander, M.E., Taylor, N.G., Dunn, A.M., Hatcher, M.J., Rosewarne, P.J., Crookes, S., MacIsaac, H.J., Xu, M., Ricciardi, A., Wasserman, R.J., Ellender, B.R., Weyl, O.L.F., Lucy, F.E., Banks, P.B., Dodd, J.A., MacNeil, C., Penk, M.R., Aldridge, D.C., Caffrey, J.M. 2017. Invader Relative Impact Potential: a new metric to understand and predict the ecological impacts of existing, emerging and future invasive alien species. J. Appl. Ecol. DOI: 10.1111/1365-2664.12849

Dunn, A.M., Torchin, M.E., Hatcher, M.J., Kotanen, P.M., Blumenthal, D.M., Byers, J.E., Coon, C., A.C., Frankel, V.M., Holt, R.D., Hufbauer, R.A., Kanarek, A.R., Schierenbeck, K.A., Wolfe, L.M., Perkins, S.E. 2012. Indirect effects of parasites in invasions. Funct. Ecol. 26, 1262-1274.

Franceschi, N., Bauer, A., Bollache, L., Rigaud, T. 2008. The effects of parasite age and intensity on variability in acanthocephalan-induced behavioural manipulation. Int. J. Parasitol. 38, 1161-1170.

Frank, S.N., Godehardt, S., Nachev, M., Trubiroha, A., Kloas, W., Sures, B. 2013. Influence of the cestode Ligula intestinalis and the acanthocephalan Polymorphus minutus on levels of heat shock proteins (HSP70) and metallothioneins in their fish and crustacean intermediate hosts. Environ. Pollut. 180, 173-179.

Giorgi, M.S., Arlettaz, R., Christe, P., Vogel, P. 2001. The energetic grooming costs imposed by a parasitic mite (Spinturnix myoti) upon its bat host (Myotis myotis). Proc. R. Soc. Lond. B Biol. Sci. 268, 2071-2075.

Grabner, D.S., Schertzinger, G., Sures, B. 2014. Effect of multiple microsporidian infections and temperature stress on the heat shock protein 70 (hsp70) response of the amphipod Gammarus pulex. Parasit. Vectors 7, 170.

Hammond, D., Pryce, A.R. 2007. Climate change impacts and water temperature. Environment Agency Science Report SC060017/SR. Bristol, UK.

Hatcher, M.J., Dunn, A.M. 2011. Parasites in ecological communities: From interactions to ecosystems. Cambridge University Press, Cambridge UK.

Hatcher, M.J., Dick, J.T.A., Dunn, A.M. 2014. Parasites that change predator or prey behaviour can have keystone effects on community composition. Biol. Lett. 10,20130879 .

Huey, R.B. 1982. Temperature, physiology, and the ecology of reptiles. C. Gans and F.H. Pough. (eds).Biology of the Reptilia,. Academic Press, New York, USA: (1982), pp. 25-91

Hulme, M., Jenkins, G.J., Lu, X., Turnpenny, J.R., Mitchell, T.D., Jones, R.G., Lowe, J., Murphy, J.M., Hassell, D., Boorman, P., McDonald, R., Hill, S. 2002. Climate change scenarios for the United Kingdom. The UKCIP Scientific Report. Tyndall Cent. Clim. Chang. Res. Sch. Environ. Sci. Univ. East Anglia, Norwich, UK. 
Iacarella, J.C., Dick, J.T.A., Alexander, M.E., Ricciardi, A. 2015. Ecological impacts of invasive alien species along temperature gradients: testing the role of environmentalmatching. Ecol. Appl. 25, 706-716.

Juliano, S.A. 2001. Non-linear curve fitting: predation and functional response curves. S.M. Scheiner and J. Gurevitch J (Eds). Design and analysis of ecological experiments. Oxford University Press, Oxford:, UK. pp. 178-196.

Keane, R.M., Crawley, M.J. 2002. Exotic plant invasions and the enemy release hypothesis. Trends Ecol. Evol. 17, 164-170.

Kelly, D.W., Bailey, R.J., MacNeil, C., Dick, J.T.A., McDonald, R.A. 2006. Invasion by the amphipod Gammarus pulex alters community composition of native freshwater macroinvertebrates. Divers. Distrib. 12, 525-534.

Kelly, D.W., Dick, J.T.A., Montgomery, W.I., MacNeil, C. 2003. Differences in composition of macroinvertebrate communities with invasive and native Gammarus spp. (Crustacea: Amphipoda). Freshw. Biol. 48, 306-315.

Kestrup, A.M., Ricciardi, A. 2009. Environmental heterogeneity limits the local dominance of an invasive freshwater crustacean. Biol. Inv. 11, 2095-2105.

Laverty, C., Dick, J.T.A., Alexander, M.E., Lucy, F.E. 2015. Differential ecological impacts of invader and native predatory freshwater amphipods under environmental change are revealed by comparative functional responses. Biol. Invasions 17, 1761-1770.

Larsen, M., Mouritsen, K.N. 2009. Increasing temperature counteracts the impact of parasitism on periwinkle consumption. Mar. Ecol. Prog. Ser. 383, 141-149.

Litzgus, J.D., Hopkins, W.A. 2003. Effect of temperature on metabolic rate of the mudturtle (Kinosternon subrubrum) J. Therm. Biol. 28, 595-600.

Maier, G., Kley, A., Schank, Y., Maier, M., Mayer, G., Waloszek, D. 2011. Density and temperature dependent feeding rates in an established and an alien freshwater gammarid fed on chironomid larvae. J. Limnol. 70, 123-128.

MacNeil, C., Fielding, N.J., Hume, K.D., Dick, J.T.A., Elwood, R.W., Hatcher, M.J.., Dunn, A.M. 2003. Parasite altered microdistribution of Gammarus pulex (Crustacea: Amphipoda). Int. J. Parasit. 33, 57-64.

Medoc, V., Spataro, T., Arditi, R. 2013. Prey: predator ratio dependence in the functional response of a freshwater amphipod. Freshwater Biol. 58, 858-865.

Morley, N.J., Lewis, J.W. 2014. Extreme climatic events and host - pathogen interactions: The impact of the 1976 drought in the UK. Ecol. Complex. 17, 1-19.

Nilsson, J. 2003. Ectoparasitism in marsh tits: costs and functional explanations. Behav. Ecol. $14,175-181$.

O'Shaughnessy, K. A., Harding, J.M., Burge, E.J. 2014. Ecological effects of the invasive parasite Loxothylacus panopaei on the flatback mud crab Eurypanopeus depressus with implications for estuarine communities. Bull. Mar. Sci. 90, 611-621. 
Ozaki, N., Fukushima, T., Harasawa, H., Kojiri, T., Kawashima, K., Ono, M. 2003. Statistical analyses on the effects of air temperature fluctuations on river water qualities. Hydrol. Process. 17, 2837-2853.

Paterson, R.A., Dick, J.T.A., Pritchard, D.W., Ennis, M., Hatcher, M.J., Dunn, A.M. 2015. Predicting invasive species impacts: a community module functional response approach reveals context dependencies. J. Anim. Ecol. 84, 453-463.

Perez-Morales, D., Espinoza, B. 2015. The role of small heat shock proteins in parasites. Cell Stress Chaper. 20, 767-780.

Portner, H.O., Knust, R. 2007. Climate change affects marine fishes through the oxygen limitation of thermal tolerance. Science 315, 95-97.

Simberloff, D., Martin, J-L., Genovesi, P., Maris, V., Wardle, D.A., Aronson, J., Courchamp, F., Galil, B., Garcia-Berthou, E., Pascal, M., Pysek, P., Sousa, R.,Tabacchi, E., Vila, M. 2013. Impacts of biological invasions: what's what and the way forward. Trends Ecol. Evol. 28, 58-66.

Sorte, C.J.B., Ibáñez, I., Blumenthal, D.M., Molinari, N.A., Miller, L.P., Grosholz, E.D., Diez, J.M., D'Antonio, C.M., Olden, J.D., Jones, S.J., Dukes, J.S. 2013. Poised to prosper? A cross-system comparison of climate change effects on native and nonnative species performance. Ecol. Lett. 16, 261-70.

Strayer, D.L. 2012. Eight questions about invasions and ecosystem functioning. Ecol. Lett. $15,1199-1210$.

Torchin, M.E., Lafferty, K.D., Dobson, A.P., McKenzie, V.J., Kuris, A.M. 2003. Introduced species and their missing parasites. Nature, 421, 628-630.

Toscano, B. J., Newsome, B., Griffen, B.D. 2014. Parasite modification of predator functional response. Oecologia 175, 345-352.

Trexler, J.C., Mcculloch, C.E., Travis, J. 1988. How can the functional response best be determined? Oecologica 76, 206-214.

Walther, G-R., Roques, A., Hulme, P.E., Sykes, M.T., Pysek, P., Kuhn, I. Zobel, M. 2009. Alien species in a warmer world: risks and opportunities. Trends Ecol. Evol. 24, 686693.

Wood, C. L., Byers, J.E., Cottingham, K.L., Altman, I., Donahue, M.J., Blakeslee, A.M.H. 2007. Parasites alter community structure. Proc. Nat. Acad. Sci. 104, 9335-9339. 


\section{Figure legends}

464 Fig. 1. Experiment 1 of this study. Functional responses of infected (i, dashed lines) and uninfected (u, solid lines) Gammarus pulex at low $\left(11^{\circ} \mathrm{C}\right.$, blue), medium $\left(16^{\circ} \mathrm{C}\right.$, orange) and high $\left(20^{\circ} \mathrm{C}\right.$, red) temperatures. Means are \pm S.D.

467

Fig. 2. Experiment 1 of this study. Mean \pm S.D. bootstrapped $(n=30)$ estimated maximum (max.) feeding rates of uninfected (dark grey) and infected (light grey) Gammarus pulex at low, medium and high temperatures. Tukey’s post-hoc tests and trend lines help illustrate the significant interaction effect.

Fig. 3. Experiment 2 of this study. Mean \pm S.D. maximum feeding rates of uninfected (dark grey), 50\% infected (middle grey) and 70\% infected (light grey) Gammarus pulex at low $\left(11^{\circ} \mathrm{C}\right)$, medium $\left(16^{\circ} \mathrm{C}\right)$ and high $\left(20^{\circ} \mathrm{C}\right)$ temperatures. Tukey's post-hoc tests and trend lines help illustrate the significant interaction effect. NS, not significant.

Table 1. Experiment $1 . \mathrm{Q}_{10}$ values associated with mean maximum feeding rates (prey killed 480 per h) at each temperature difference for infected and uninfected Gammarus pulex.

\begin{tabular}{lccc}
\hline \multicolumn{1}{c}{ Infection status } & $\Delta$ Temp $\left({ }^{\circ} \mathrm{C}\right)$ & $\begin{array}{c}\text { Mean maximum } \\
\text { feeding rates }\end{array}$ & Q10 Value \\
\hline Infected & Overall & $0.63-1.39$ & 2.41 \\
& $11-16$ & $0.63-1.00$ & 2.57 \\
Uninfected & $16-20$ & $1.00-1.39$ & 2.23 \\
& Overall & $0.39-0.85$ & 2.37 \\
& $11-16$ & $0.39-0.68$ & 3.11 \\
& $16-20$ & $0.68-0.85$ & 1.55 \\
\hline
\end{tabular}


Table 2. Experiment 2. Q10 values associated with mean prey eaten at each temperature 483 difference and infected proportion of Gammarus pulex.

\begin{tabular}{cccc}
\hline Infected proportion (\%) & $\Delta$ Temp $\left({ }^{\circ} \mathrm{C}\right)$ & Mean prey eaten & Q10 Value \\
\hline 0 & Overall & $107-144$ & 1.39 \\
& $11-16$ & $107-134$ & 1.56 \\
& $16-20$ & $134-144$ & 1.19 \\
\multirow{2}{*}{50} & Overall & $119-203$ & 1.81 \\
& $11-16$ & $119-178$ & 2.23 \\
& $16-20$ & $178-203$ & 1.38 \\
70 & Overall & $154-228$ & 1.54 \\
& $11-16$ & $154-192$ & 1.55 \\
& $16-20$ & $192-228$ & 1.53 \\
\hline
\end{tabular}

484

485

486

487

488

489

Table 3. First order linear coefficients (lc) from logistic regressions for Gammarus pulex infection status with Echinorhynchus truttae and experimental temperature combinations. All indicate Type II functional responses (see Section 3).

\begin{tabular}{lccc}
\hline Parasite status & Temperature $\left.\mathbf{~}^{\mathbf{0}} \mathbf{C}\right)$ & $\begin{array}{l}\text { Linear coefficient } \\
\left(\mathbf{1}^{\text {st }} \text { order }\right)\end{array}$ & $\boldsymbol{P}$ value \\
\hline Infected & 11 & -0.051 & $<0.001$ \\
16 & -0.073 & $<0.001$ \\
Uninfected & -0.079 & $<0.001$ \\
& 11 & -0.079 & $<0.001$ \\
& 16 & -0.084 & $<0.001$ \\
& 20 & -0.092 & $<0.001$
\end{tabular}

490

491

492

493

494

495

496 
497

Figure 1

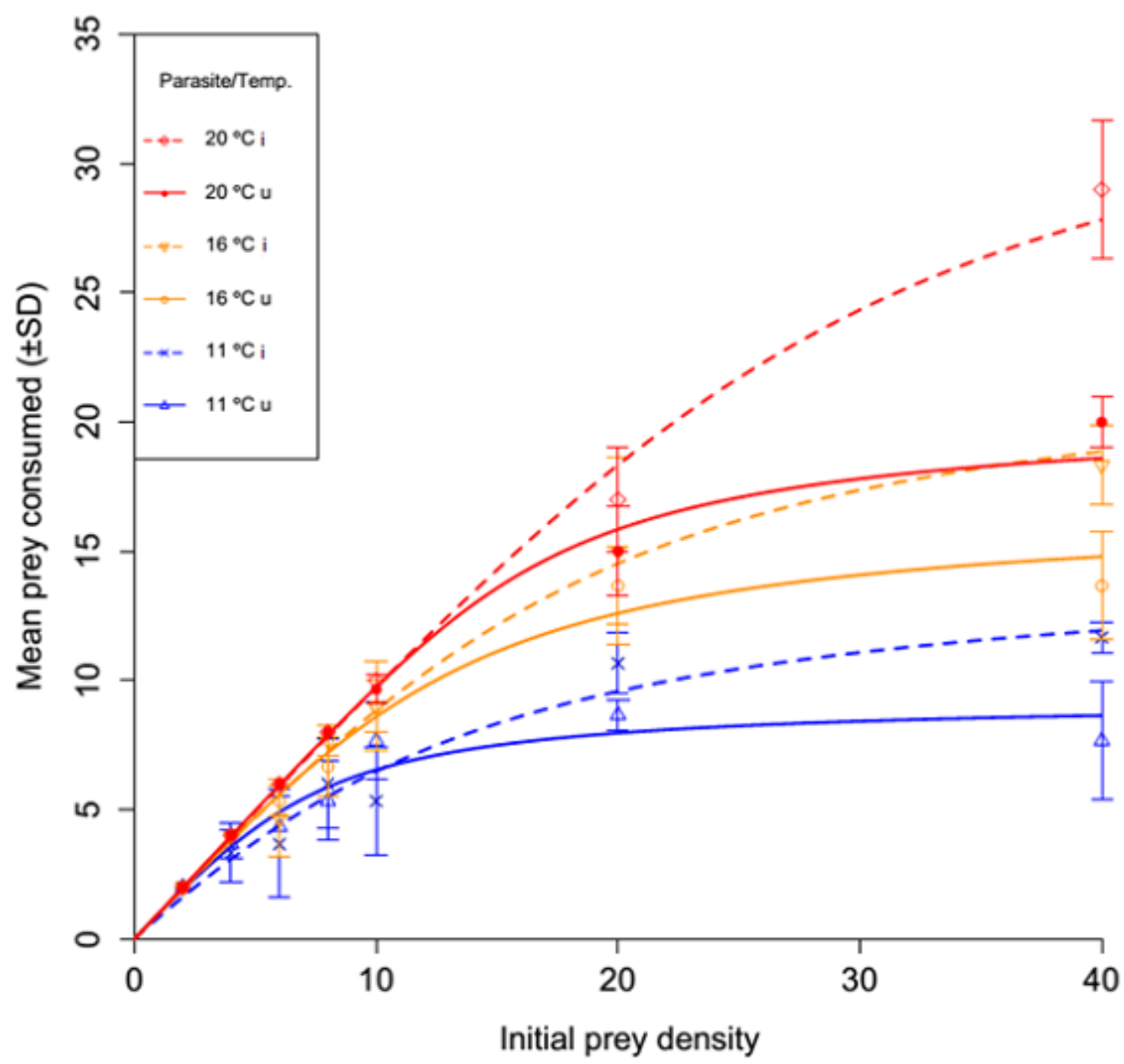

498

Figure 2

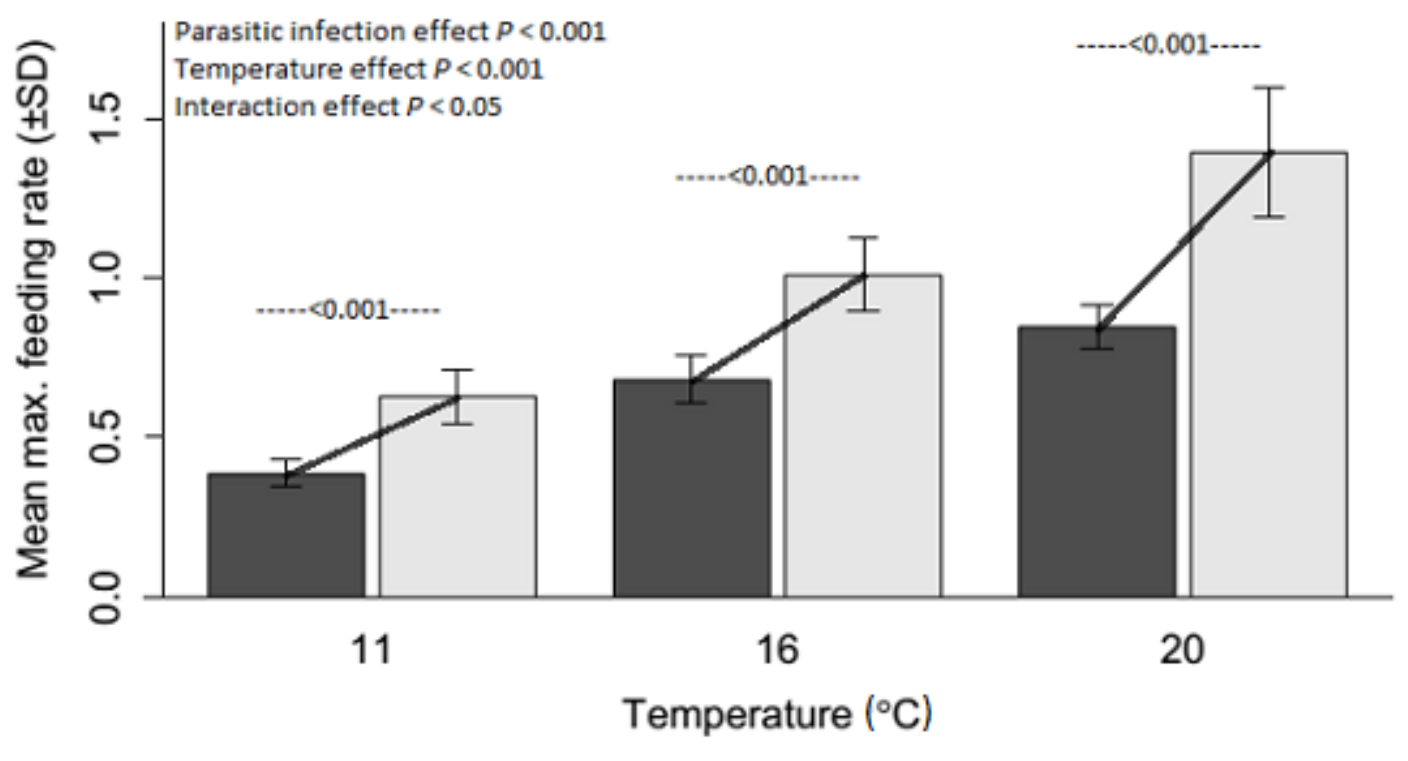


Figure 3

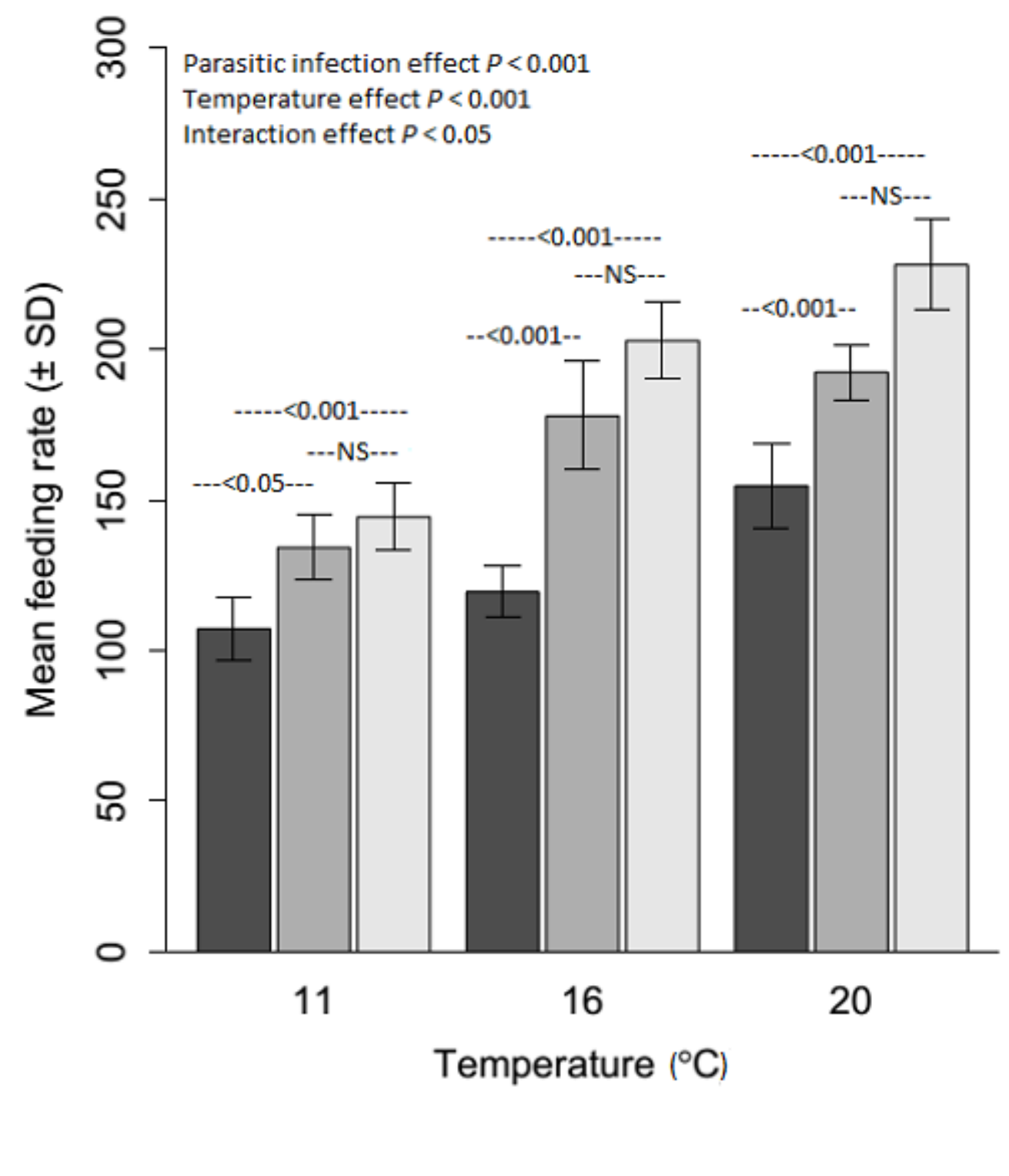

